\title{
Erratum: Torpor: The Rise and Fall of 3-Monoiodothyronamine from Brain to Gut-From Gut to Brain?
}

\author{
Frontiers Production Office* \\ Frontiers Media SA, Lausanne, Switzerland
}

Keywords: T1AM, thyroxine, monoiodothyronamine, apolipoprotein B-100, hibernation, immunoassay, torpor, mass spectrometry

\section{An erratum on}

Torpor: The Rise and Fall of 3-Monoiodothyronamine from Brain to Gut-From Gut to Brain? by Glossmann HH, Lutz OMD. Front Endocrinol (2017) 8:118. doi:10.3389/fendo.2017.00118

\section{Reason for Erratum}

Due to typesetting errors, three mistakes were introduced in the published article.

In the section "7.5. Gut Microbiota, Cecotrophy, Coprophagy", page 6, left column, 2nd line, should read:

Correct: Rats ingest between 50 and 65\% of their feces (82).

Incorrect: Rats ingest between 50 and 65 of their feces (82).

In the section "7.6. Serum Levels in Humans", page 6, left column, 2nd paragraph, 9th line, should read:

\section{OPEN ACCESS}

Approved by:

Frontiers in Endocrinology Editorial

Office, Frontiers Media SA,

Switzerland

${ }^{*}$ Correspondence:

Frontiers Production Office

production.office@frontiersin.org

Specialty section:

This article was submitted to

Thyroid Endocrinology,

a section of the journal

Frontiers in Endocrinology

Received: 22 June 2017

Accepted: 22 June 2017

Published: 10 July 2017

Citation:

Frontiers Production Office (2017) Erratum: Torpor: The Rise and Fall of 3-Monoiodothyronamine from Brain to Gut-From Gut to Brain?

Front. Endocrinol. 8:158. doi: 10.3389/fendo.2017.00158
Correct: $M S / M S$ measurements reported that T1AM concentrations in human sera or plasma are far below $1 \mathrm{nM}$ (70). Roy et al. proved excellent stability of deuterated and non-deuterated T1AM in pooled human serum by incubating it for 24 hours at $37^{\circ} \mathrm{C}$ (57).

Incorrect: MS/MS measurements reported that T1AM concentrations in human sera or plasma are far below $1 \mathrm{nM}(57,70)$ proved excellent stability of deuterated and non-deuterated T1AM in pooled human serum by incubating it for $24 \mathrm{~h}$ at $37^{\circ} \mathrm{C}$.

In the section "8. CONCLUSION", page 6, right column, the last sentence should read:

Correct: One can agree with Hoefig et al. (16), that it will take much less time today compared to earlier discoveries, to unravel the mysteries of the novel $T_{4}$ metabolite.

Incorrect: One can agree with (16) that it will take much less time today compared to earlier discoveries, to unravel the mysteries of the novel $T_{4}$ metabolite.

The publisher apologizes for these mistakes. These errors do not change the scientific conclusions of the article in any way.

The original article was updated.

Conflict of Interest Statement: The authors declare that the research was conducted in the absence of any commercial or financial relationships that could be construed as a potential conflict of interest.

Copyright ( $\odot 2017$ Frontiers Production Office. This is an open-access article distributed under the terms of the Creative Commons Attribution License (CC BY). The use, distribution or reproduction in other forums is permitted, provided the original author $(s)$ or licensor are credited and that the original publication in this journal is cited, in accordance with accepted academic practice. No use, distribution or reproduction is permitted which does not comply with these terms. 